\title{
Unification among contradictions: Germany and Europe face globalization in crisis
}

\begin{abstract}
After World War II, Germany was divided in zones of occupation between the Allied victors (Soviet Union, US, UK and France). Soviet-occupied regions quickly become the German Democratic Republic (East Germany), as the remainder comprised the Federal Republic of Germany (West Germany). Across four decades, both German states (divided, after 1961, by the infamous Berlin Wall) become economic powers amidst the warring blocks of Cold War. East Germany was the second largest planned economy in COMECON and West Germany, the runner-up in the European Economic Community (EEC), one of the major ancestors of the current European Union (EU). East Germany followed the Soviet line of one-party system. In West Germany, two great parties dominated domestic politics since 1949 (the end of military occupation). Christian Democracy (CDU) ruled for 28 years, starting with Konrad Adenauer. Social Democracy (SPD) ruled for another 13 years. At the end of Cold War, West Germany incorporated East Germany in October 3, 1990. Conversely, the major political forces of a reunified Germany remained those of West Germany. Ever since, CDU and SPD obtained an average sum of $70 \%$ of votes since the Reunification.
\end{abstract}

Volume 3 Issue I - 2019

\author{
Carlos Frederico Pereira da Silva Gama \\ Director of International Affairs, Universidade Federal do \\ Tocantins, Brazil
}

\begin{abstract}
Correspondence: Carlos Frederico Pereira da Silva Gama, Director of International Affairs, International Relations Professor, Universidade Federal do Tocantins, UFT, Brazil, Email carlosfredericopdsg@gmail.com
\end{abstract}

Received: October 17, 2017 | Published: January 08, 2019

\section{Introduction}

Across Cold War, the political platforms of Christian Democracy and Social Democracy converged to a remarkably resilient consensus. Firstly, West Germany was framed as a democratic rule-of-law state. Secondly, it remained an industrial capitalist economy. In terms of international security, West Germany was compulsively disarmed since 1949. In this uncomfortable role, the new state focused regional stability and pushed for a European Rapid Reaction Force, in order to put aside (in due time) the nuclear warheads placed in both sides of the Wall by rival superpowers. Finally, West Germany provided a launching pad for an integrated Europe towards the East. The Ospolitik of Social Democratic Willy Brandt symbolized this challenge to bipolarity since the early 1970s. One generation after the Maastricht Treaty, ${ }^{1}$ EU comprised 28 states, including several former members of COMECON. Reunified Germany was the first state to recognize Croatia and Slovenia during the Yugoslav Civil War. Germany kept a high profile in United Nations-led peace operations across the 1990s. ${ }^{a}$ More controversially, it took part in military operations in Europe such as NATO's intervention in Kosovo, only a decade after the fall of the Berlin Wall. ${ }^{2-4}$ Under Christian Democrat Helmut Kohl and Social Democrat Gerhard Schroeder, the new German state was a key G-8 player, an industrial and trade superpower. Benefitting from Reunification and immigration from East Europe and the Middle East, it had EU's largest economy and population Giddens. ${ }^{5}$

Facing this winning streak, the international community was surprised that Christian Democrat Angela Merkel found so much trouble before obtaining a fourth consecutive mandate in 2017. ${ }^{\mathrm{b}}$ In a disquieting sign, the far right achieved its best voting performance since the Weimar Republic-including a significant number of seats at the German parliament, the Bundestag. The turning point was the 2008 financial crisis. As the Schroeder-led SPD-Green coalition fell

aGama, Carlos Frederico Pereira da Silva (2016). Após a Guerra, Estabilidade? Mudanças nas Operações de Paz da ONU (1992-2000). Jundiaí: Paco Editorial. ${ }^{\mathrm{b}} \mathrm{Gama}$, Carlos Frederico Pereira da Silva (2017). "Unificação entre Contradições: Alemanha, Europa e as crises da globalização". MUNDORAMA. 2017. apart, voting turnout dropped dramatically (at around 10\%). Between 2005 and 2009, CDU and SPD lost 7 million votes. For the first time in Reunited Germany, their joint voting share fell under $60 \%$ (Figure $1 \& 2$ ). ${ }^{6}$ The answers to this crisis changed the EU. For long considered as pillars of the integration process, free market policies and freedom of movement, out of a sudden, were converted into a prolonged recession and a deep humanitarian crisis. Communitarian institutions-for decades, ranked among innovators in international relations and public policies-suddenly become part of the problem. Instead of focusing the convergence of policies between memberstates and other social agents Hooghe, ${ }^{7}$ the actions of the EU acquired a coercive intensity unseen at the regional scale. Integrated policies become subject to strict systems of rules and punishments, closer to the International Monetary Fund than to the age-old aspirations of Jean Monnet and Robert Schuman. Merkel's ascension to the status of Prime Minister symbolically marks the shift in EU policies during the crisis. Against the backdrop of the most indebted economies in Europe (the PIIGS), such policies were perceived as competitive devices that, in the long run, favor a German hegemony. Dani Rodrik ${ }^{8}$ framed such a dramatic shift in the content of communitarian policies as a regional integration experiment among hyper globalization.

Another rapid reversal in expectations took place in security issues. Germany was a privileged destination for refugees fleeing Syria during the civil war. In a remarkable display of international solidarity, under Merkel it received more than 1 million people in a couple years. Nevertheless, electoral support for the "open doors" policy waned after the sexual assaults during 2015's New Year's Eve in Cologne (attributed to Middle Eastern immigrants) and the terrorist attacks in a Christmas market in Berlin in 2016 (claimed by ISIS). Such reluctance was also noticeable in the public sphere, where hate speech reappeared under the guise of "freedom of expression". Contrasting with images of Europe as a multilevel governance system, ${ }^{\mathrm{d}}$

'Rodrik Dani (2011). The Globalization Paradox: Democracy and the Future of the World Economy. New York: W.W. Norton.

¿Hooghe, Lisbet \& Marks, Gary (2003)."Unraveling the Central State, but How? Types of Multi-level Governance in American Political Science Review. 
sovereign states bounce back to the spotlights of a community fearful of populism, where political anxieties regarding the status of borders turn the clock back to 1991. e Apart from an ongoing Brexit, EU faces the challenges brought by independence referendums in Scotland and Catalunya. During crisis, integration promises get less persuasive. Europe remains in flux, ${ }^{\mathrm{f}}$ less a community of fate than an experiment where sudden discontinuities share space with lessons learned. Unintended consequences ${ }^{g}$ of globalization turned the successful ascension of postwar Germany into another chapter of the ongoing crisis of liberal democracies ${ }^{\mathrm{h}}$ in the 21 st century. Victory in peace came at a price, and with a bitter taste.

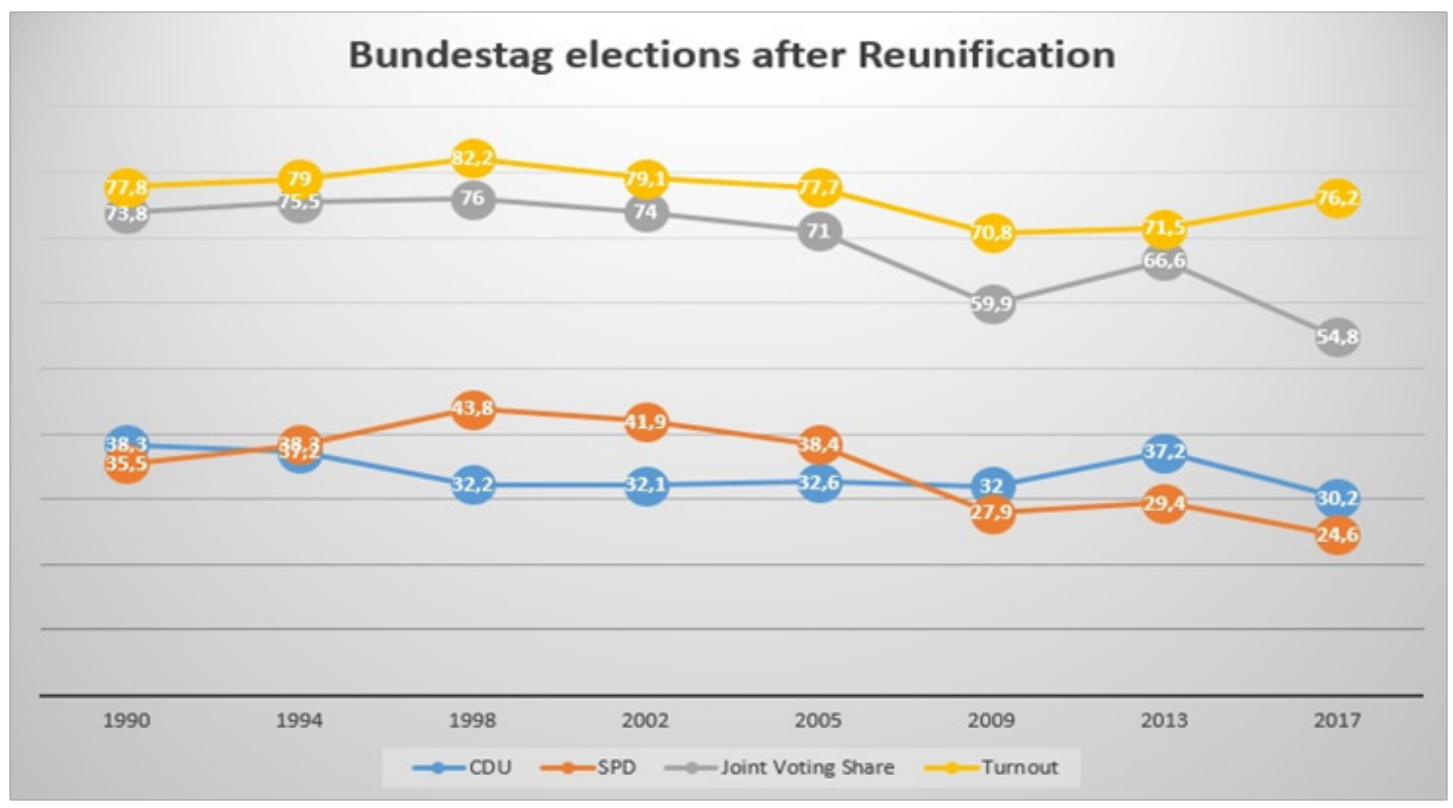

Figure I Bundestag elections after Reunification. ${ }^{a}$

aFederal Republic of Germany (2017). Election Resources. 2017.

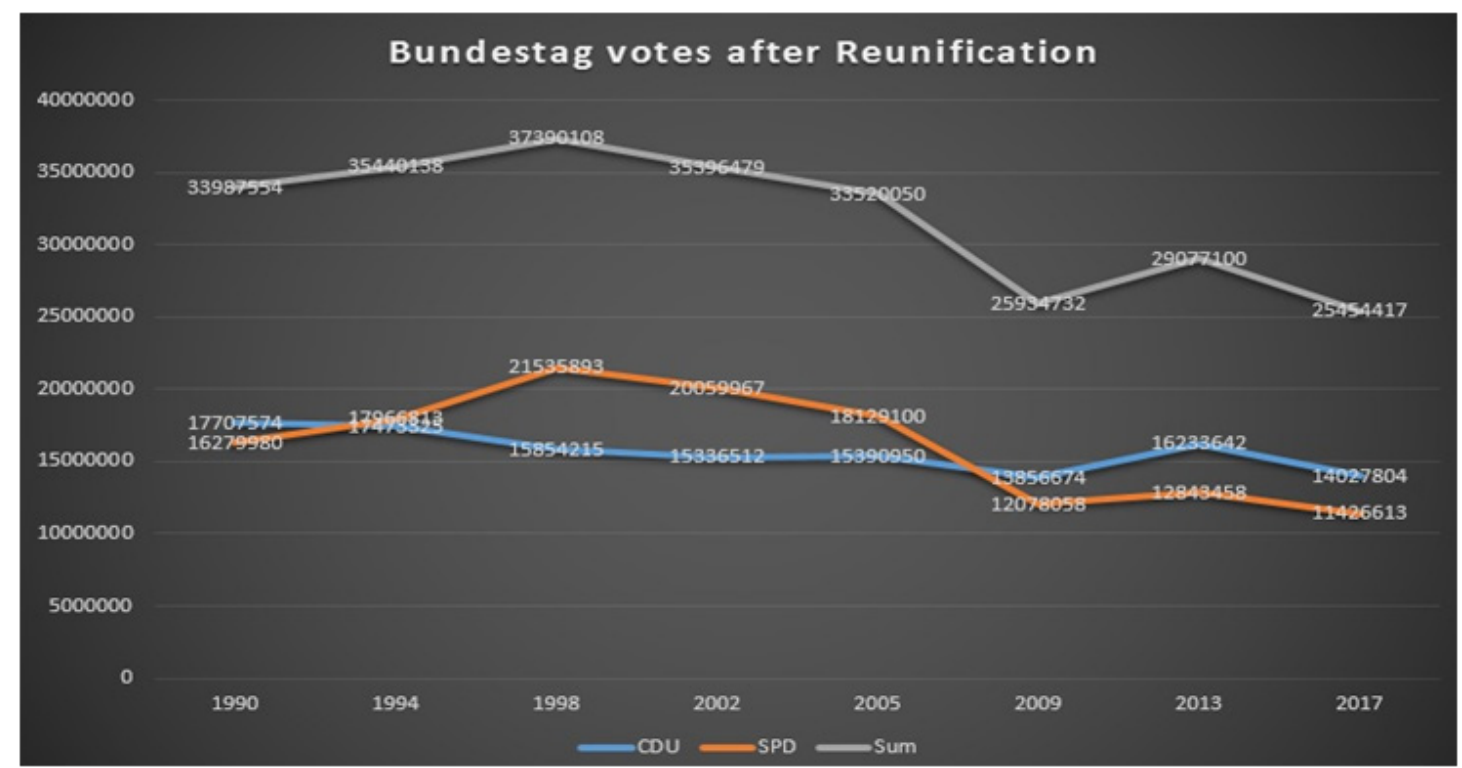

Figure 2 Bundestag votes after Reunification. ${ }^{\mathrm{b}}$

blbid.

\section{Acknowledgments}

None.

\footnotetext{
${ }^{\mathrm{e}}$ Gama, Carlos Frederico Pereira da Silva (2017). A Eleição Presidencial na França e a União Europeia em crise. NEMRI.

${ }^{\mathrm{f} G a m a}$, Carlos Frederico Pereira da Silva (2017). Jovens Ruínas da Integração Europeia. MUNDORAMA.

${ }^{\mathrm{g}}$ Gama, Carlos Frederico Pereira da Silva (2017). Jovens Ruínas da Integração Europeia. MUNDORAMA.
}

\section{Conflicts of interest}

The author declares that no conflict of interest exists in publishing this article.

\section{References}

1. Maastricht Treaty. Election Resources. Federal Republic of Germany. 2017.

hGama, Carlos Frederico Pereira da Silva (2017). Vitórias Inconclusivas: o Desgaste da Democracia Liberal. NEMRI. 
2. Gama, Carlos Frederico Pereira da Silva. Após a Guerra, Estabilidade? Mudanças nas Operações de Paz da ONU (1992-2000). Jundiaí: Paco Editorial; 2016.164 p.

3. Gama, Carlos Frederico Pereira da Silva. A Eleição Presidencial na França e a União Europeia em crise. NEMRI; 2017. 255 p.

4. Gama, Carlos Frederico Pereira da Silva. Jovens Ruínas da Integração Europeia. MUNDORAMA. 2017.

5. Giddens, Anthony. The Consequences of Modernity. Stanford: Stanford University Press; 1990. 188 p.
6. Gama, Carlos Frederico Pereira da Silva. Vitórias Inconclusivas: o Desgaste da DemocraciaLiberal. NEMRI. 2017. 25 p.

7. Hooghe Lisbet, Marks Gary. Unraveling the Central State, but How? Types of Multi-level Governance. American Political Science Review. 2013;97(2):233-243.

8. Rodrik, Dani. The Globalization Paradox: Democracy and the Future of the World Economy. New York: WW Norton; 2011. 368 p. 